九州大学学術情報リポジトリ

Kyushu University Institutional Repository

\title{
The Effect of Bellmouth Radius and Venturi Restrictor Length on The Power and Torque of BM-9' s Engine
}

\section{Fauzun}

Mechanical and Industrial Engineering Department, Faculty of Engineering, Universitas

Cahyo Wibi Yogiswara

Mechanical and Industrial Engineering Department, Faculty of Engineering, Universitas

https://doi.org/10.5109/4480732

出版情報: Evergreen. 8 (2)，pp.477-483，2021-06. Transdisciplinary Research and Education Center for Green Technologies, Kyushu University

バージョン：

権利関係 : 


\title{
The Effect of Bellmouth Radius and Venturi Restrictor Length on The Power and Torque of BM-9's Engine
}

\author{
Fauzun $^{1, *}$, Cahyo Wibi Yogiswara ${ }^{1}$ \\ ${ }^{1}$ Mechanical and Industrial Engineering Department, Faculty of Engineering, Universitas Gadjah Mada, \\ Yogyakarta, Indonesia \\ *E-mail: fauzun71@ugm.ac.id
}

(Received November 20, 2020; Revised May 19, 2021; accepted June 21, 2021).

\begin{abstract}
One of the rules of Student Formula SAE is air intake must have a restrictor located after the throttle body with $20 \mathrm{~mm}$ maximum diameter. It causes engine power and torque decreased. To increase engine performance, modify the bellmouth radius and venturi restrictor length are some of options. The authors analyzed the effect of them on power and torque produced by KTM 450 SXF engine of Bimasakti UGM's 9th generation car (BM-9). The authors made 9 design variations then simulated by Ricardo Wave 2016.1 and Ansys Fluent 18.1 software. The result is, greater the bellmouth radius and venturi restrictor length produced higher value of peak power and peak torque.
\end{abstract}

Keywords: Bellmouth; Restrictor; Air Intake; Engine Performance; Ricardo Wave; Ansys Fluent.

\section{Introduction}

Student Formula SAE Japan (FSAEJ) is an international class formula car competition held by the Japan Society of Automotive Engineers (JSAE). FSAEJ in 2019 has entered the 17th year competition. In the competition, students are required to be able to design and manufacture formula cars according to the regulatory standards of SAE International. One of the rules in this competition is to use a four-stroke gasoline engine with a maximum capacity of 710 cc. This competition is divided into two events, namely static event and dynamic event. Static event are design event, cost and manufacturing event, and business presentation, while dynamic event compete acceleration, skidpad, autocross, and endurance and efficiency ${ }^{1)}$.

One of the improvements in car performance to get maximum results at dynamic events is to modify the air intake. The basic function of an air intake system is to provide the throttle body with air where it is then mixed with the fuel and then sent to combustion chamber-5). Air intake is important to determine the power and torque that will be generated by the engine. Modified air intake must be designed so that the engine can produce power and torque as needed during the competition ${ }^{6,7}$. Modification of air intake must be based on SAE rules, which are: air intake must have single throttle body and must has a restrictor located after throttle body with maximum diameter $20 \mathrm{~mm}$. This restrictor at air intake made power and torque produced by engine decrease from the engine specification in standard condition. It was because of the amount of air affects the homogeneous of air-fuel mixture. Then, the lean or rich fuel combustion mode must be adjusted to the competition necessity 8,9 . But, one advantage of restrictor is that it provides high velocity of air intake into engine. The flow of air attains a supersonic flow $(M=1)$. Here the team worked on the optimization of pressure and velocity of air which enhance the engine to offer better performance with minimum engine pull ${ }^{10,11}$.

The possible way to increase power and torque produced by engine are modify the bellmouth radius and the length of restrictor with venturi shape ${ }^{12-15)}$. This is supported by previous study which found that simple bellmouth radius has coefficient of discharge 0.84 , while plain pipe has coefficient of discharge 0.64. The advantage performance of simple bellmouth radius used at air intake is $27 \%$ over a plain pipe. The selection of restrictor with venturi shape based on previous study which found that venturi shape has coefficient of discharge 0.975 , higher than orifice shape 0.6 . The venturi shape also has the lower pressure loss than the orifice shape ${ }^{2,16,17)}$. Modify the convergent and divergent length of venturi restrictor can produce the lower value of pressure loss inside the restrictor ${ }^{18,19)}$.

The objective of this study is to know the effect of bellmouth radius and venturi restrictor length at air intake on the power and torque produced by KTM 450 SX-F engine used by Bimasakti UGM's car $9^{\text {th }}$ generation (BM9) that compete in FSAE Japan. The novelty of this study is analyzing the effect of bellmouth radius at air intake on the power and torque of KTM 450 SX-F engine. There are many papers researching about the effect of venturi restrictor length at air intake of Student Formula SAE car, but the authors have not found any paper researching on the effect of bellmouth radius. 


\section{Methods}

In this research, the powertrain system of Bimasakti UGM's car $9^{\text {th }}$ generation (BM-9) is used to be simulated in Ricardo Wave software. The design of air intake system of BM-9 used in this research is shown in Fig. 1 (a). The air intake system is made up of the bellmouth, throttle body, restrictor, plenum, and intake runner. The engine is made up of the intake port, cylinder, exhaust port, and the exhaust system are made up of the adaptor, header, muffler, and tail pipe ${ }^{6,20)}$.

Before the authors run the simulation of air intake system of BM-9, the authors must validate the simulation methods of Ricardo Wave software. This validation is done by comparing data of power and torque Bimasakti UGM's car $8^{\text {th }}$ generation (BM-8) based on wheel dynamometer test (dyno test) result to Ricardo Wave simulation result. The difference between them must be under $5 \%$ so the simulation methods of Ricardo Wave software is valid. The design of air intake system of BM8 used in this validation is shown in Fig. 1 (b).

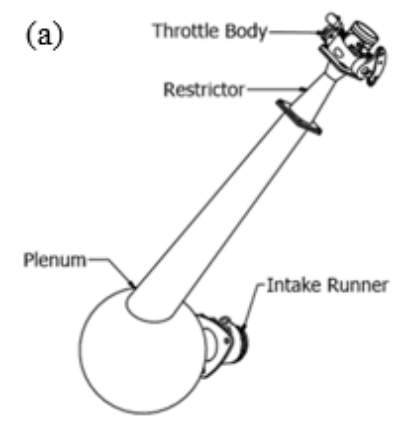

(b)

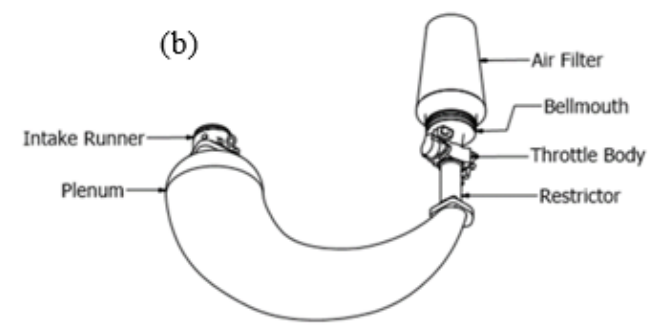

Fig. 1: (a) Air intake system of BM-9 (b) Air intake system of BM-8

\subsection{Data Collection}

Each powertrain system component is modelled according to the existing dimension. The specification data of KTM 450 SX-F engine is shown in Table $1^{20,21}$.

Table 1. KTM 450 SX-F engine specification

\begin{tabular}{|l|l|}
\hline \multicolumn{1}{|c|}{ Data } & \multicolumn{1}{c|}{ Value } \\
\hline Engine Type & Single Cylinder \\
\hline Displacement & $449 \mathrm{cc}$ \\
\hline Cycle & 4 strokes \\
\hline Bore/Stroke & $95 \mathrm{~mm} / 63.4 \mathrm{~mm}$ \\
\hline Compression Ratio & $12.8: 1$ \\
\hline Valve Configuration & SOHC \\
\hline Number of Speeds & 4 \\
\hline
\end{tabular}

The wall temperature of the entire powertrain system is measured using the Testo 835-T2 infrared thermometer and the result can be seen real-time. Table 2 shows the data result of the wall temperature gauging ${ }^{20)}$.

Table 2. Data of powertrain system wall temperature

\begin{tabular}{|l|l|c|}
\hline \multicolumn{1}{|c|}{ Part } & \multicolumn{1}{c|}{ Material } & Wall Temperature \\
\hline Bellmouth & Aluminum & $303 \mathrm{~K}$ \\
\hline Throttle body & Aluminum & $302 \mathrm{~K}$ \\
\hline Restrictor & Aluminum & $304 \mathrm{~K}$ \\
\hline Plenum & PVA & $304 \mathrm{~K}$ \\
\hline Intake runner & Aluminum & $310 \mathrm{~K}$ \\
\hline Intake port & Aluminum & $341 \mathrm{~K}$ \\
\hline Engine block & Aluminum & $341 \mathrm{~K}$ \\
\hline Exhaust port & Aluminum & $368 \mathrm{~K}$ \\
\hline Exhaust adaptor & Stainless Steel & $530 \mathrm{~K}$ \\
\hline Exhaust header 1 & Monel & $534 \mathrm{~K}$ \\
\hline Exhaust header 2 & Monel & $532 \mathrm{~K}$ \\
\hline Exhaust header 3 & Monel & $435 \mathrm{~K}$ \\
\hline Muffler pipe & Stainless Steel & $392 \mathrm{~K}$ \\
\hline Muffler & Stainless Steel & $327 \mathrm{~K}$ \\
\hline Tail pipe & Stainless Steel & $307 \mathrm{~K}$ \\
\hline
\end{tabular}

\subsection{Ricardo Wave Modelling}

After all data is compiled, the model for Ricardo WAVE simulation is ready to be created using WaveBuild subsoftware. Fig. 2 shows the powertrain system simulation model on BM-920,22).

\subsection{Ansys Fluent Setup}

Ansys Fluent software used in this research is to find the pressure loss (pressure inlet - pressure outlet) value in the venturi restrictor. There are k-epsilon and k-omega viscous models in Ansys Fluent. To perform the CFD analysis for this design model, the authors used k-epsilon. It is based on the literature reviewed that k-epsilon is used for moderate velocity objects such as cars, bikes, etc. since the FSAE race cars are ranged in this speed criteria. While, k-omega is applied for high velocity objects such as planes, jet planes, etc. since the FSAE race cars doesn't reach that much high speed ${ }^{12,14,23)}$.

The boundary conditions used in this simulation are ${ }^{13)}$ :

Inlet : Total pressure $=101325 \mathrm{~Pa}$.

Outlet : Mass flow rate $=0.0703 \mathrm{~kg} / \mathrm{s}$.

The value of inlet total pressure is based on the atmospheric pressure of $101325 \mathrm{~Pa}$. The domain of inlet section is at the entrance region of bellmouth. While, the value of mass flow rate is based on the choked flow equation below. The domain of outlet section is at the end of venturi restrictor. 


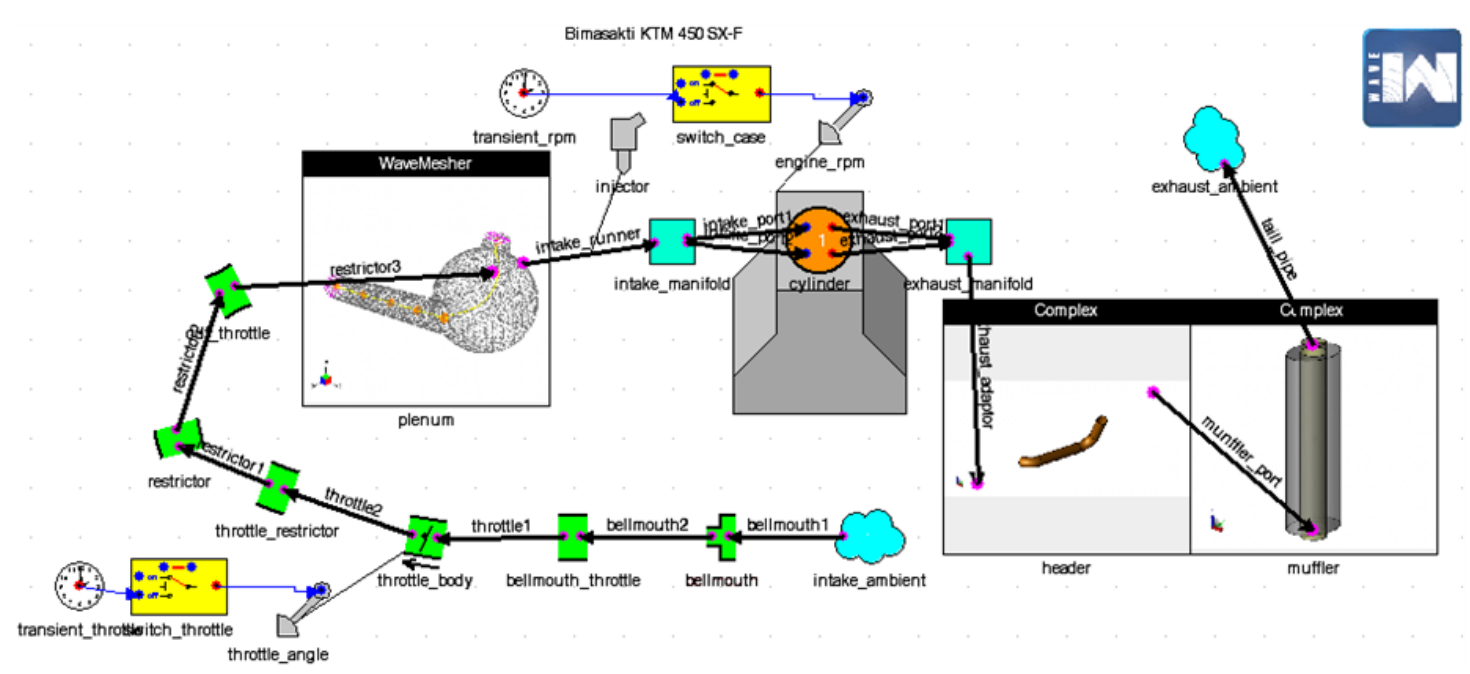

Fig. 2: Ricardo Wave simulation model

The value of mass flow rate is based on the choked flow equation ${ }^{14,15)}$ :

$$
\dot{m}=\frac{A P}{\sqrt{T}} \sqrt{\frac{\gamma}{R}}\left(\frac{\gamma+1}{2}\right)^{-\frac{\gamma+1}{2(\gamma-1)}}
$$

According to the above equation the mass flow rate at outlet was calculated as given below:

$$
\begin{array}{ll}
A & =0.001256 \mathrm{~m}^{2}(20 \mathrm{~mm} \text { restriction }) \\
P & =101325 \mathrm{~Pa} \\
T & =303 \mathrm{~K} \\
\gamma & =1.4 \\
R & =0.286 \mathrm{KJ} / \mathrm{Kg}-\mathrm{K} \\
\dot{m} & =0.0703 \mathrm{~kg} / \mathrm{s}
\end{array}
$$

\section{Result and Discussion}

\subsection{Validation of Simulation Methods}

Fig. 3 shows the graph result of BM-8 wheel dynamometer test. Figure 4 and Figure 5 show the graph result of power and torque of BM-8 based on Ricardo Wave simulation. The graph between the wheel dynamometer test and simulation result are similar and indicated that the simulation methods used in this study is valid.

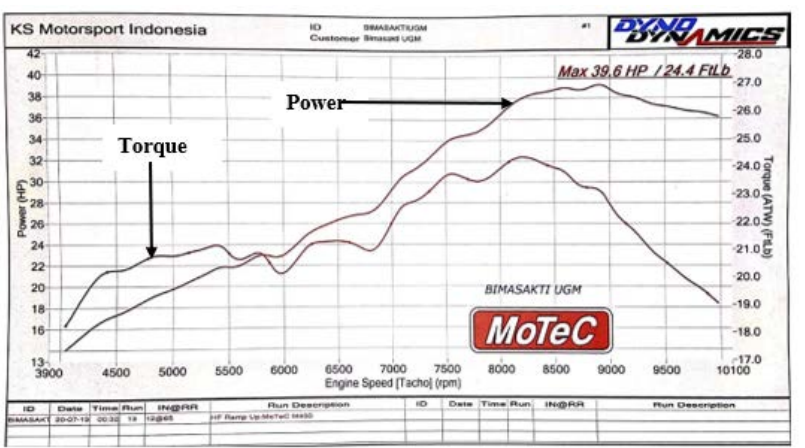

Fig. 3: BM-8 wheel dynamometer test power and torque graphs

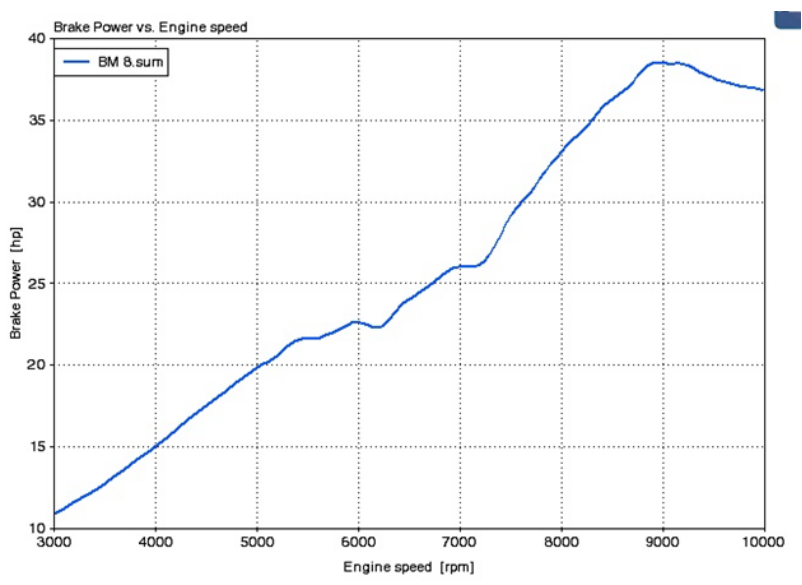

Fig. 4: BM-8 simulation result power graph

Fig. 4 shows that the power graph constantly increase since engine speed $3000 \mathrm{rpm}$ to $10000 \mathrm{rpm}$, but there is a little power drop between $6000 \mathrm{rpm}$ to $7000 \mathrm{rpm}$ range. This condition shows similarity to the wheel dynamometer result power graph. The simulation scored peak power $38.6 \mathrm{hp}$ at $9000 \mathrm{rpm}$.

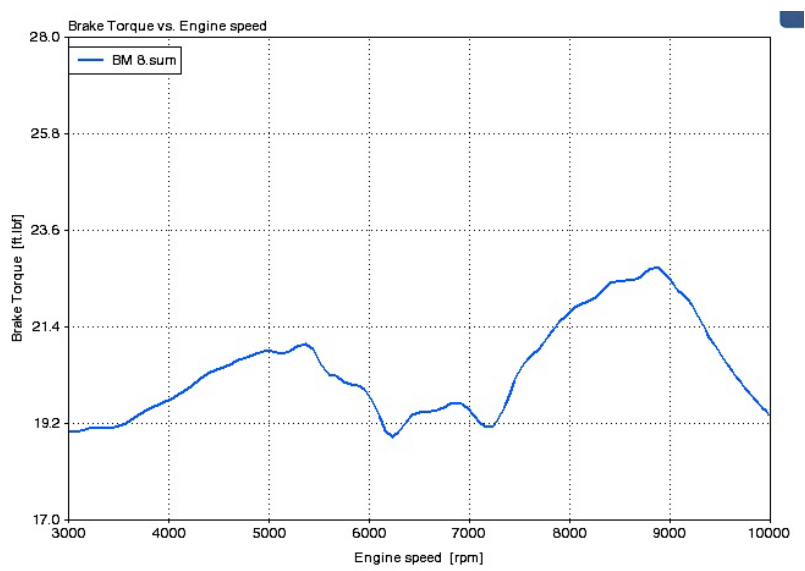

Fig. 5: BM-8 simulation result torque graph 
Fig. 5 shows that the torque graph increases since engine speed $3000 \mathrm{rpm}$ to $5500 \mathrm{rpm}$. Then, the graph shows torque drop between $5500 \mathrm{rpm}$ to $7500 \mathrm{rpm}$. This condition shows similarity to the wheel dynamometer result torque graph. This simulation scored peak torque $22.6 \mathrm{ft} . \mathrm{lb}$ at $8800 \mathrm{rpm}$.

Table 3 and Table 4 show the calculation of difference in result based on graph of Fig. 3, Fig. 4, and Fig. 5. The difference in result between wheel dynamometer test of BM-8 and simulation Ricardo Wave of BM-8 is under 5\%, so the simulation methods used in this research is valid.

Table 3. Power validation result of simulation methods

\begin{tabular}{|c|c|c|c|}
\hline \multirow{2}{*}{$\begin{array}{c}\text { Engine } \\
\text { speed (rpm) }\end{array}$} & \multicolumn{3}{|c|}{ Value of BM-8 Power (hp) } \\
\hline & $\begin{array}{c}\text { Simulation } \\
\text { result }\end{array}$ & $\begin{array}{l}\text { Dyno test } \\
\text { result }\end{array}$ & $\begin{array}{c}\text { \% difference } \\
\text { value }\end{array}$ \\
\hline 4000 & 15.12 & 14 & 8 \\
\hline 5000 & 19.98 & 20 & 0.1 \\
\hline 6000 & 22.63 & 23 & 1.61 \\
\hline 7000 & 26.01 & 29 & 10.31 \\
\hline 8000 & 33.13 & 36.5 & 9.23 \\
\hline 9000 & 38.48 & 39 & 1.33 \\
\hline 10000 & 36.87 & 36 & 2.41 \\
\hline \multicolumn{3}{|c|}{ \% mean difference value } & 4.37 \\
\hline
\end{tabular}

Table 4. Torque validation result of simulation methods

\begin{tabular}{|c|c|c|c|}
\hline \multirow[b]{2}{*}{$\begin{array}{c}\text { Engine } \\
\text { speed (rpm) }\end{array}$} & \multicolumn{3}{|c|}{ Value of BM-8 Torque (ft.lb) } \\
\hline & $\begin{array}{l}\text { Simulation } \\
\text { result }\end{array}$ & $\begin{array}{l}\text { Dyno test } \\
\text { result }\end{array}$ & $\begin{array}{c}\text { \% difference } \\
\text { value }\end{array}$ \\
\hline 4000 & 19.76 & 18.5 & 6.81 \\
\hline 5000 & 20.83 & 21 & 0.81 \\
\hline 6000 & 19.72 & 20.5 & 3.8 \\
\hline 7000 & 19.37 & 21.8 & 11.11 \\
\hline 8000 & 21.74 & 23.5 & 7.48 \\
\hline 9000 & 22.51 & 22.5 & 0.04 \\
\hline 10000 & 19.37 & 19 & 1.94 \\
\hline \multicolumn{3}{|c|}{ \% mean difference value } & 4.29 \\
\hline
\end{tabular}

\subsection{Design Variation and Simulation Result}

In this research, several variations of the bellmouth radius and divergent length of venturi restrictor are made to get the best air intake design to optimize power and torque produced by KTM 450 SX-F engine of BM-9. There are 9 design variations. Number 1 to 3 have same bellmouth radius of $30 \mathrm{~mm}$ with different venturi length. Number 4 to 6 have same bellmouth radius of 15 with different venturi length. Number 7 to 9 have no bellmouth with different venturi length. All of 9 design variation simulated in Ricardo Wave software to analyze the power and torque values.

Fig. 6 shows the assembled design of air intake system used in this research. The throttle body used in this research has diameter of $36 \mathrm{~mm}$ and the outlet diameter of venturi restrictor is $40 \mathrm{~mm}$ with the length of convergent section is $25 \mathrm{~mm}$. The design variations and the results of the simulation are as follows on Table 5 and Table 6.

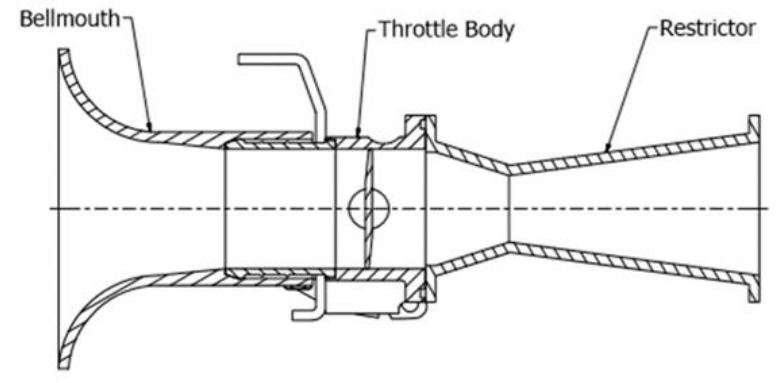

Fig. 6: Design assembly of air intake system

Table 5. Design variations

\begin{tabular}{|c|c|c|}
\hline $\begin{array}{c}\text { Design } \\
\text { Number }\end{array}$ & $\begin{array}{c}\text { Bellmouth radius } \\
\text { (mm) }\end{array}$ & $\begin{array}{c}\text { Divergent length of } \\
\text { venturi (mm) }\end{array}$ \\
\hline 1 & 30 & 55 \\
\hline 2 & 30 & 75 \\
\hline 3 & 30 & 95 \\
\hline 4 & 15 & 55 \\
\hline 5 & 15 & 75 \\
\hline 6 & 15 & 95 \\
\hline 7 & Not applied & 55 \\
\hline 8 & Not applied & 75 \\
\hline 9 & Not applied & 95 \\
\hline
\end{tabular}

Table 6. Ricardo Wave simulation result

\begin{tabular}{|c|c|c|}
\hline $\begin{array}{c}\text { Design } \\
\text { Number }\end{array}$ & Peak power & Peak torque \\
\hline 1 & 37.56 hp @9600rpm & 28.74 Nm @9100rpm \\
\hline 2 & 37.80 hp @9800rpm & 29.08 Nm @9000rpm \\
\hline 3 & 37.94 hp@9300rpm & 29.38 Nm @9000rpm \\
\hline 4 & 37.25 hp @9500rpm & 28.58 Nm @9000rpm \\
\hline 5 & 37.50 hp@9400rpm & 28.91 Nm @9000rpm \\
\hline 6 & 37.65 hp @9400rpm & 29.26 Nm @9000rpm \\
\hline 7 & 36.85 hp @9800rpm & 28.34 Nm @9000rpm \\
\hline 8 & 37.18 hp @9600rpm & 28.68 Nm @8900rpm \\
\hline 9 & 37.48 hp @9400rpm & 28.97 Nm @8900rpm \\
\hline
\end{tabular}

Design 1 to 9 simulation result graph can be seen in Fig. 7 and Fig. 8 below.

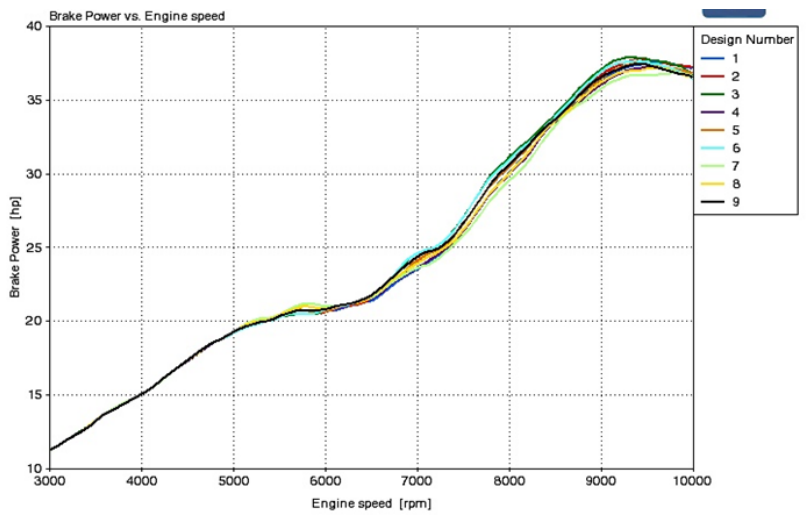

Fig. 7: Design 1 to 9 simulation result power graph 
Fig. 7 shows that the power graphs for all design variations are almost similar. It is constantly increase since engine speed $3000 \mathrm{rpm}$ to $10000 \mathrm{rpm}$. The power graph of Design 3 is always on top position with the peak power value of $39.4 \mathrm{hp}$ at $9300 \mathrm{rpm}$.

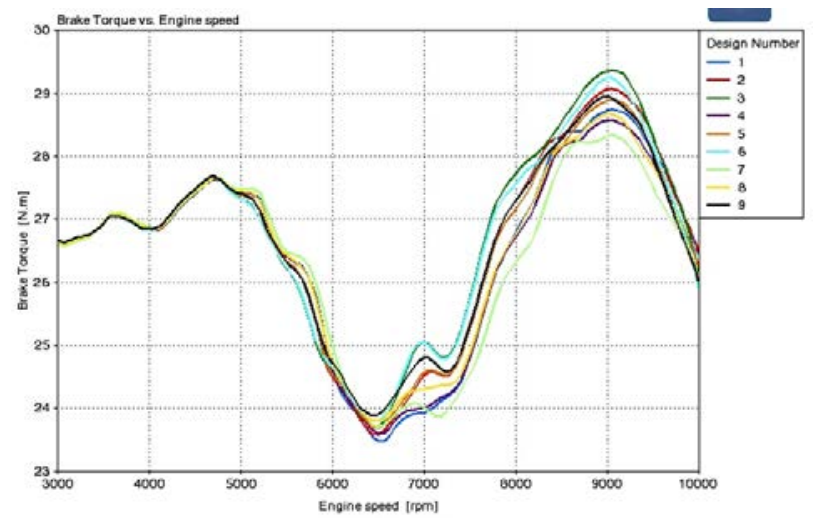

Fig. 8: Design 1 to 9 simulation result torque graph

Fig. 8 shows that the torque graphs decrease at 5000 rpm to $7000 \mathrm{rpm}$ range. Then, it is increase at $7000 \mathrm{rpm}$ to $9000 \mathrm{rpm}$ range and then decrease. All the design variations show similar pattern. The peak torque was produced by Design 3 with the value of $29.38 \mathrm{Nm}$ at 9000 rpm.

Then, the authors chose 3 sample design that would be simulated in Ansys Fluent software to analyze the pressure loss values. From Table 6, Fig. 7, and Fig. 8, the authors characterized the best, middle, and worst design variation based on the peak power and peak torque result. It is known from Table 6 that the highest value of peak power and peak torque is in Design 3, while the lowest value of peak power and peak torque is in Design 7, and Design 5 is on middle result. So, these 3 sample designs would be simulated in Ansys Fluent.

\subsection{Ansys Fluent Simulation Result}

Three samples of design had been chosen to be simulated in Ansys Fluent, which are the best, middle, and worst result. Ansys Fluent used to prove the power and torque result based on pressure loss data. Table 7 shows the main characteristic of each design and the result of pressure loss in each sample design. The authors calculate the difference pressure value at the inlet bellmouth and at the end of venturi restrictor to determine pressure loss.

Table 7. Result of pressure loss

\begin{tabular}{|c|c|c|c|c|}
\hline $\begin{array}{c}\text { Design } \\
\text { No. }\end{array}$ & $\begin{array}{c}\text { Bellmouth } \\
\text { radius } \\
\mathbf{( m m )}\end{array}$ & $\begin{array}{c}\text { Divergent } \\
\text { length of } \\
\text { venturi } \\
\mathbf{( m m )}\end{array}$ & $\begin{array}{c}\text { Pressure } \\
\text { Loss } \\
\mathbf{( P a )}\end{array}$ & $\begin{array}{c}\text { Outlet } \\
\text { Velocity } \\
\mathbf{( m / s )}\end{array}$ \\
\hline 3 & 30 & 95 & 4713 & 77.8738 \\
\hline 5 & 15 & 75 & 4966 & 77.1849 \\
\hline 7 & Not applied & 55 & 5063 & 77.8656 \\
\hline
\end{tabular}

These below Fig. 9 to Fig. 11 show the contour of pressure for each design variations.

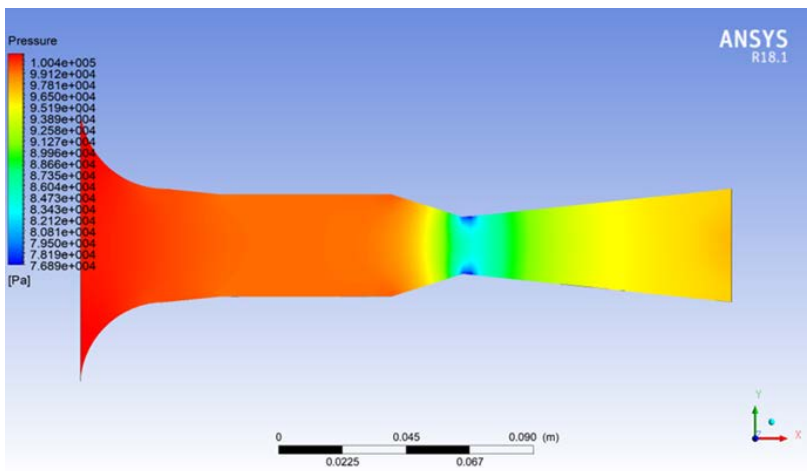

Fig. 9: Contour of pressure Design 3

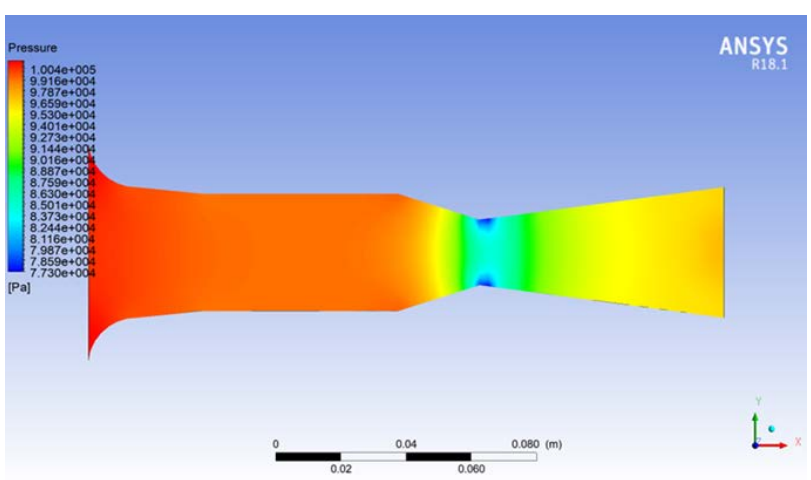

Fig. 10: Contour of pressure Design 5

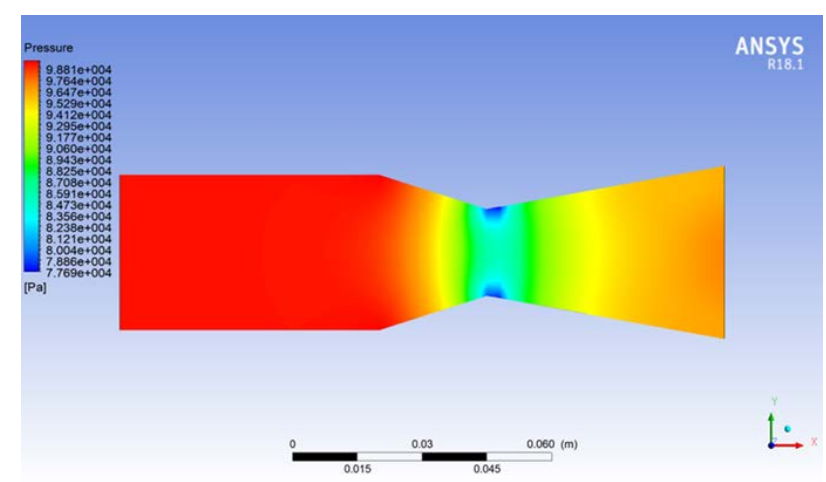

Fig. 11: Contour of pressure Design 7

From pressure contour of Figure 9, Figure 10, and Figure 11, it can be seemed that pressure value dropped from the inlet bellmouth to the throat section of the venturi restrictor, and then increased at the end of venturi restrictor. The increase in pressure value that occurs at the end of the venturi restrictor cannot increase by the pressure value at the inlet bellmouth. This is due to a reduction in the diameter of the throat restrictor by $20 \mathrm{~mm}$.

From Table 7, it is known that Design 3 produces the lowest pressure loss value compared to Design 5 and Design 7. Whereas, Design 7 produces the highestpressure loss value compared to Design 3 and Design 5. The data also matches the results of peak power and peak 
torque values based on Ricardo Wave simulation before. Design 3, with radius of bellmouth $30 \mathrm{~mm}$ and divergent length of venturi restrictor $95 \mathrm{~mm}$ produces the best peak power and peak torque values, and also produces the lowest pressure loss value in the restrictor. Design 5, with radius of bellmouth $15 \mathrm{~mm}$ and divergent length of venturi restrictor $75 \mathrm{~mm}$ produces the middle result of peak power, peak torque, and pressure loss values. Design 7 , with no bellmouth and has divergent length of venturi restrictor 55 $\mathrm{mm}$ produces the worst peak power and peak torque values, and also produces the highest-pressure loss value in the restrictor. Meanwhile, the value of outlet velocity on the outlet venturi restrictor did not show a significant difference, it has consistent value of $77 \mathrm{~m} / \mathrm{s}$.

These results indicated that greater bellmouth radius and longer divergent length of venturi restrictor can produced higher value of peak power and peak torque with lower value of pressure loss. In other words, higher pressure loss value made lower peak power and peak torque values ${ }^{24,25)}$. The relation between pressure and power is defined by mean effective pressure (MEP). The pressure loss occurs in the restrictor made lower MEP value. It is a fictious pressure that, if it acted on the piston during entire power stroke, would produce the same amount of net work as that produced during the actual cycle.

That is :

$$
W_{\text {net }}=M E P \times \text { Displcement volume }
$$

The MEP can be used as a parameter to compare the performances of engine in equal size. The engine with a larger value of MEP delivers more net work per cycle and thus performs better ${ }^{25}$.

\section{Conclusion}

In this research, it can be concluded that the use of Ricardo Wave and Ansys Fluent software for designing the air intake system is very efficient because it can perform simulation with many variations, at no cost. Then, we knew that bellmouth can increase the peak power and peak torque values, which is proven by the result between Design 3 and Design 7. The best design variation in this research is bellmouth design with $30 \mathrm{~mm}$ of radius and venturi restrictor design with $95 \mathrm{~mm}$ of divergent length that produced peak power of $37.94 \mathrm{hp}$ at $9300 \mathrm{rpm}$ and peak torque of $29.38 \mathrm{Nm}$ at $9000 \mathrm{rpm}$, also produced pressure loss of $4713 \mathrm{~Pa}$ in the restrictor.

\section{Nomenclature}

$\begin{array}{ll}A & \text { area }\left(\mathrm{m}^{2}\right) \\ P & \text { total pressure }(\mathrm{Pa}) \\ T & \text { total temperature }(\mathrm{K}) \\ R & \text { gas constant }(\mathrm{kJ} / \mathrm{kg}-\mathrm{K}) \\ \gamma & \text { specific heat ratio }(-) \\ \dot{m} & \text { mass flow rate }(\mathrm{kg} / \mathrm{s}) \\ M E P & \text { mean effective pressure }(\mathrm{Pa}) \\ W_{\text {net }} & \text { net work }(\mathrm{kJ})\end{array}$

\section{References}

1) "2020 Formula SAE Rules," http:// students.sae.org/cds/formulaseries/rules/ (accesed May 1, 2020).

2) A. Singhal, "Designing \& Validating a New Intake Manifold for a Formula SAE Car," International Journal of Engineering and Technology, 5 (7) 463467 (2016). ISSN : 2278-0181.

3) C. Liu, J. You, C. Sung, and C. Huang, "Modified Intake and Exhaust System For Piston-Type Compressed Air Engines," Energy, 90 515-524 (2015). doi : 10.1016/j.energy.2015.07.085.

4) R. S. Mazzaro, S. Hanriot, R. J. Amorim, and P. Almeida, "Numerical Analysis of The Air Flow In Internal Combustion Engine Intake Ducts Using Herschel-Quincke Tubes," Applied Acoustic, 165 110 (2020). doi : 10.1016/j.apacoust.2020.107310.

5) G. Vichi, L. Romani, L. Ferrari, and G. Ferrara, "Development of An Engine Variable Geometry Intake System For A Formula SAE Application," Energy, $81 \quad 930-941 \quad$ (2015). doi : 10.1016/j.egypro.2015.12.149.

6) Fauzun, and A. B. Nugraha, "The Influence of Plenum Geometry Toward Engine," AIP Conference Proceedings, $2248 \quad$ (020004) 1-9 (2020). doi:10.1063/5.0019099.

7) F. Hosein, "Modelling, Simulation and Validation of a Top/Central-Fed Air-Intake System for a FSAE Restricted 600cc Four-Stroke Engine," International Journal of Scientific \& Engineering Research, 7 (12) 406-427 (2016). ISSN : 2229-5518.

8) S. Abikusna, B. Sugiarto, and I. Yamin, "Utilization Analysis of Bioethanol (Low Grade) and Oxygenated Additive to COV and Gas Emissions on SI Engine," Evergreen, 7 (1) 43-50 (2020). doi : 10.5109/2740940.

9) D. A. Sugeng, W. J. Yahya, A. M. Ithnin, B. H. Kusdi, M. A. A. Rashid, I. Baihuddin, N. A. Mazlan, and H. A. Kadir, "Experimental Comparison of Smoke Opacity and Particulate Matter Emissions with the Use of Emulsion Fuel," Evergreen, 7 (3) 452-457 (2020).

10) M. V. Kumar, and S. Murugesan, "Analysis and Development of Restrictor for Parallel Twin Engine in FSAE Cars," International Journal of Engineering and Technology, 7 (3.6) 311-314 (2018). doi : 10.14419/ijet.v7i3.6.15122.

11) M. Melaika, A. Rimkus, and T. Vipartas, "Air Restrictor and Turbocharger Influence For The Formula Student Engine Performance," Engineering, 187 402-407 (2017). doi : 10.1016/j.proeng.2017.04.392.

12) P. M. Sawan, S. S. Sawan, P. N. Gurav, P. S. Nivalkar and P. S. Waghmare, "Analysis of Air Intake for Formula Student Race Car," International Research Journal of Engineering and Technology, 5 (4) 42544258 (2018). ISSN : 2395-0072.

13) A. Sayyed, "Air Flow Optimization Through An 
Intake System for A Single Cylinder Formula Student (FSAE) Race Car," International Journal of Engineering Research \& Technology, 6 (1) 183-188 (2017). ISSN : 2278-0181.

14) P. A. Shinde, "Research and Optimization of Intake Restrictor for Formula SAE Car Engine," International Journal of Scientific and Research Publications, 4 (4) 1-5 (2014). ISSN : 2250-3153.

15) H. Han-chi, H. Huang and Y. Bai, "Optimization of Intake and Exhaust System for FSAE Car Based on Orthogonal Array Testing," International Journal of Engineering and Technology, 2 392-396 (2012).

16) A. Tiwari, A. Lad, S. Patel, and C. S. Mistry, "Development of Bell Mouth For Low Speed Axial Flow Compressor Testing Facility," Proceedings of the Asian Congress on Gas Turbines, (2016).

17) A. Singhal, "Designing \& Validating a New Intake Manifold for a Formula SAE Car," International Journal of Engineering and Technology, 5 (7) 463467 (2016). ISSN : 2278-0181.

18) A. Halawa, B. Elhadidi, S. Yoshida, "Aerodynamic Performance Enhancement Using Active Flow Control on DU96-W-180 Wind Turbine Airfoil," Evergreen, 5 (1) 16-24 (2018). doi : 10.5109/1929723

19) A. S. Syahrul, M. Normah, J. Oh, and A. Robiah, "Entropy Generation Minimization of Two-Phase Flow in a Mini Channel with Genetic Algorithm," Evergreen, 6 (1) 39-43 (2019). hdl : 2324/2321004.

20) Fauzun, and A. Kurniawan, "Ricardo WAVE Simulation on the Effect of Exhaust Header Geometry to the Power and Torque of the UGM's FSAE Engine," International Journal of Engineering and Technology, 9 3338-3348 (2017). doi : 10.21817/ijet/2017/v9i4/170904139.

21) KTM Inc., "Owner's Manual KTM 450 SX-F," Mattighofen, 2019.

22) Ricardo Inc., "Wave Software Manual," 2016.

23) Ansys Inc., "Ansys Fluent Tutorial Guide," Canonsburg, 2018.

24) A. S. Pamitran, M. A. Budiyanto, and R. Maynardi, "Analysis of ISO-Tank Wall Physical Exergy Characteristic : Case Study of LNG Boil-off Rate from Retrofitted Dual Fuel Engine Conversion," Evergreen, 6 (2) 134-142 (2019). hdl : 2324/2321007.

25) Y. A. Cengel and M. A. Boles, "Thermodynamics: An Engineering Approach," New York: McGraw-Hill, 2006. 